\title{
CLOSURE OF LARGE WOUND WITH RUBBER ELASTIC CIRCULAR STRIPS - CASE REPORT
}

\author{
Sutura elástica com fita circular de borracha para fechamento de grande ferida operatória - relato de caso
}

Andy PETROIANU, Kelly Renata SABINO, Luiz Ronaldo ALBERTI

From the Serviço de Cirurgia Geral e Núcleo de Pós-Graduação e Pesquisa (General Surgery Service and Post-Graduation Nucleus), Santa Casa de Belo Horizonte, Belo Horizonte, MG, Brazil

\section{Correspondence:}

Andy Petroianu

E-mail: petroian@medicina.ufmg.br

Financial source: none

Conflicts of interest: none

Received for publication: 20/11/2012

Accepted for publication: 02/05/2013

\section{INTRODUCTION}

T he technique of elastic suture was described by Raskin ${ }^{4}$ in a review article on acute vascular lesions in the upper limbs after crushing arm and forearm with the development of compartment syndrome. This author used an elastic suture to approximate the edges of fasciotomy and prevent bloody retraction. Leite et al. ${ }^{3}$ added in the application of subcutaneous and superficial fascia, in order to avoid additional suffering the edge of the skin, which could worsen the condition of the wound to this technique. This modification improved the aesthetic appearance and location prevented the formation of the lateral wound scars.

The objective of this report is to present a new technique for closure of extensive surgical wounds through elastic suture, using circular elastic rubber bands.

\section{CASE REPORT}

Woman with 49 years old was admitted in Santa Casa de Belo Horizonte, Brazil, in good general condition but with a tumor in hypogastric region with dimensions of $25 \times 15 \mathrm{~cm}$ in diameter and $12 \mathrm{~cm}$ high. The evolution of neoplasia was 10 years and had a bleeding ulcer on its top. A CT scan showed that the tumor has not plagued the muscle layer or other deep structures. Physical examination and additional imaging tests showed no signs of metastases. A biopsy of this lesion diagnosed dermatofibrosarcoma. The tumor was completely removed with wide lateral and deep margins, including muscle fascia, which was macroscopically free of disease. The remaining wound area was of $20 \times 15 \mathrm{~cm}$ in diameter and $4 \mathrm{~cm}$ deep. The approximation of the wound edges was done by means of elastic suture. Two thin circular rubber bands - usually used to hold bundles of cash - were sterilized by autoclaving and sutured to the edges of the wound, $1 \mathrm{~cm}$ from the wound area. Simple 2-0 nylon was used in suturing. These tapes were zigzag positioned. This procedure was performed under local anesthesia with $1 \%$ lidocaine. After five days, the wound edges were already very close to each other and the two rubber strips failed to exert traction on them. With local anesthesia, they were replaced by a single circular rubber tape, which kept the draw for the approximation of the edges. On the $20^{\text {th }}$ postoperative day, the skin closure was completed and there was no need to suture the skin. The patient was discharged on that day, with the wound closed and showing good healing aspect. She continues to be followed on an outpatient basis after over 14 months and is very pleased with the outcome of the treatment. No recurrence or metastasis sarcoma were recorded.

\section{DISCUSSION}

The treatment of large accidental or surgical wounds require special care for their resolution, which can require significant time and multiple surgical procedures, depending on their characteristics and causes ${ }^{1,2,3,5,6}$. The advantages found in wound closure of this report were: technical ease of manufacture of elastic suture, reduced aggression to the body, short hospital stay and good acceptance by the patient. There were no complications such as infection, rejection, tissue necrosis or scar retraction, and healing showed good final aesthetic appearance. The minimum financial cost and availability of this feature in all hospitals are also highlighted advantages of this procedure.

Alternatives to rebuild this type of wound would be great with grafts or skin flaps. However, 
such operations, are more complex in their size and location, creating new sores which, in turn, must also be treated ${ }^{1,6}$. These behaviors are accompanied by pain, increased incidence of infections, scar retraction, rejection and failure. The realization of more complex surgical procedures requires skilled and experienced professional in plastic surgery. Costs and hospital stay are also high ${ }^{2,5,6}$. Moreover, the operation presented in this report is easy to be conducted even by professionals without much experience or special surgery, possible in any surgical centers, even smallers. This technique has been used by the authors in other situations, such as raw areas after withdrawal of burns, removal of Marjolin ulcer, severe soft tissue infections, various skin tumors located on the trunk and limbs, the closure of abdominal wall after laparostomies, all with good results.

\section{REFERENCES}

1. Costa SRP, Henriques AC. Giant dermatofibrossarcoma protuberans on the abdominal wall. Einstein 5: 63-65, 2007.

2. Dorai AA, Halim AS. Extended double pedicle free tensor fascia latae myocutaneous flap for abdominal wall reconstruction. Singapore Med J 48: e141-145, 2007.

3. Leite NM, Reis FB, Christian RW. Tratamento de ferimentos deixados abertos com o método da sutura elástica. Rev Bras Ortoped 31: 687-689, 1996.

4. Raskin KB. Acute vascular injuries of the upper extremity. Hand Clin 9: 115-130, 1993.

5. Samie FH, Kane JM 3rd, Zeitouni NC. Repair of large abdominal defects with prostheses following Mohs micrographic surgery. Dermatol Surg 34: 403-406, 2008.

6. Sarabahi S, Bajaj SP, Bhatnagar A, Sharma M. Reconstruction of abdominal wall by whole thigh flap. J Plast Reconstr Aesthet Surg 59:1429-1432, 2006. 